\title{
Constraints on Black Sea outflow to the Sea of Marmara during the last glacial-interglacial transition
}

\author{
Candace Major ${ }^{\star, a}$, William Ryan ${ }^{a}$, Gilles Lericolais ${ }^{b}$ and Irka Hajdas ${ }^{c}$ \\ a Lamont-Doherty Earth Observatory of Columbia University, Palisades, NY, USA \\ ${ }^{b}$ IFREMER, F-29280, Plouzane Cedex, France \\ ${ }^{c}$ AMS ${ }^{14} \mathrm{C}$ lab, IPP ETH Hoenggerberg, CH-8093, Zurich, Switzerland \\ *: Corresponding author : Tel.: +1-845-365-8758; Fax: +1-845-365-3182; email: major@ldeo.columbia.edu
}

\begin{abstract}
:
New cores from the upper continental slope off Romania in the western Black Sea provide a continuous, high-resolution record of sedimentation rates, clay mineralogy, calcium carbonate content, and stable isotopes of oxygen and carbon over the last $20000 \mathrm{yr}$ in the western Black Sea. These records all indicate major changes occurring at $15000,12800,8400$, and $7100 \mathrm{yr}$ before present. These results are interpreted to reflect an evolving balance between water supplied by melting glacial ice and other river runoff and water removed by evaporation and outflow. The marked retreat of the Fennoscandian and Alpine ice between 15000 and $14000 \mathrm{yr}$ is recorded by an increase in clays indicative of northern provenance in Black Sea sediments. A short return toward glacial values in all the measured series occurs during the Younger Dryas cold period. The timing of the first marine inflow to the Black Sea is dependent on the sill depths of the Bosporus and Dardanelles channels. The depth of the latter is known to be $-80 \pm 5 \mathrm{~m}$, which is consistent with first evidence of marine inundation in the Sea of Marmara around $12000 \mathrm{yr}$. The bedrock gorge of the Bosporus reaches depths in excess of $-100 \mathrm{~m}$ (relative to present sea level), though it is now filled with sediments to depths as shallow as $-32 \mathrm{~m}$. Two scenarios are developed for the connection of the Black Sea with the Sea of Marmara. One is based on a deep Bosporus sill depth (effectively equivalent to the Dardanelles), and the other is based on a shallow Bosporus sill (less than $-35 \mathrm{~m}$ ). In the deep sill scenario the Black Sea's surface rises in tandem with the Sea of Marmara once the latter connected with the Aegean Sea, and Black Sea outflow remains continuous with inflowing marine water gradually displacing the freshwater in the deep basin. The increase in the $\delta^{18} \mathrm{O}$ of mollusk shells at $12800 \mathrm{yr}$ and the simultaneous appearance of inorganic calcite with low $\delta^{18} \mathrm{O}$ is compatible with such an early marine water influx causing periodic weak stratification of the water column. In the shallow sill scenario the Black Sea level is decoupled from world sea level and experiences rise and fall depending on the regional water budget until water from the rising Sea of Marmara breaches the shallow sill. In this case the oxygen isotope trend and the inorganic calcite precipitation is caused by increased evaporation in the basin, and the other changes in sediment properties reflect climate-driven river runoff variations within the Black Sea watershed. The presence of saline ponds on the Black Sea shelf circa $9600 \mathrm{yr}$ support such evaporative drawdown, but a sensitive geochemical indicator of marine water, one that is not subject to temperature, salinity, or biological fractionation, is required to resolve whether the sill was deep or shallow.
\end{abstract}

Keywords: deglaciation; Younger Dryas; sapropel; stable isotopes; clay mineralogy 


\section{INTRODUCTION}

The Black Sea lies at the interior end of a series of basins connected to the open ocean via straits and their sills (Ünlüata et al., 1989). High salinity water from the Mediterranean travels from the Aegean Sea, through the Dardanelles Sill and the Sea of Marmara, to enter the Black Sea as an undercurrent in the narrow Bosporus Strait. The inflow has led to a density stratification. As a result the Black Sea waters below $\sim 200 \mathrm{~m}$ have been anoxic for the past 7,160 yrs (Jones and Gagnon, 1994).

The Sea of Marmara and the Aegean Sea also show evidence of past anoxia (Aksu et al., 1995). Their anoxia preceded that in the Black Sea and has been attributed to freshwater outflow from the Black Sea (Aksu et al., 1999; Cagatay et al., 2000; Olausson, 1961; Stanley and Blanpied, 1980). Most researchers consider the Black Sea outflow to have been continuous through both glacial and interglacial time (Chepalyga, 1984; Kvasov, 1968; Kvasov, 1975; Ross and Degens, 1974). The outflow would have been augmented by displacement of the deep water stored behind the Bosporus Sill once the connection from the Mediterranean is established (Lane-Serff et al., 1997).

An alternate view suggests that outflow was intermittent and ceased when the Black Sea behaved like the modern Caspian Sea and dropped its surface below its outlet (Ozdogan, 1990). Shelf-beveling erosion surfaces (Ryan et al., 1997) and wave cut terraces at -80 to $-155 \mathrm{~m}$ (Ballard et al., 2000; Dimitrov, 1982; Kuprin et al., 1974; Shimkus et al., 1980) required a significant regression that could have transformed the Bosporus Strait into a subaerial valley (Scholten, 1974).

This paper addresses the question of a continuous or intermittent outflow from the Black Sea using a time series of paleoenvironmental indicators in sedimentary cores collected from the 
continental slope beyond the mouth of the Danube River. The conclusions drawn from the new observations are, however, dependent upon assumptions about the Bosporus sill over which exchange took place. Though a shallow sill similar to the present Bosporus configuration is most commonly proposed, seismic reflection profiles and boreholes clearly show a bedrock gorge beneath this strait partly filled with sediment (Yilmaz and Sakinc, 1990). Mollusk shells sampled above the floor of the gorge and $70 \mathrm{~m}$ below present sea level have been dated by

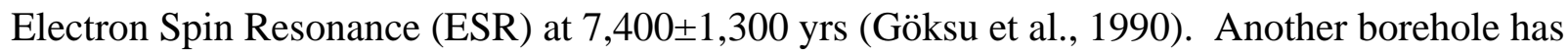
26,100 year old shells (radiocarbon dated) above the bedrock at -105 m (Cagatay et al., 2000). Thus the possibility of a deep Black Sea/Marmara connection in the past cannot be excluded.

\section{Methods}

Two sediment cores were recovered by the Kullenburg method of piston coring in 240 and 378 meters of water, respectively (Figure 1; Table 1). Navigation was acquired with differential GPS. The cores were positioned along high-resolution sub-bottom profiles used to correlate the strata from one site to the other.

Table 1: Black Sea cores (BLaSON, Le Suroit, 1998)

\begin{tabular}{|l|l|l|l|l|}
\hline Core name & Latitude & Longitude & Water depth $(\mathrm{m})$ & Length $(\mathrm{cm})$ \\
\hline BLKS9809 & $44^{\circ} 05.23^{\prime}$ & $30^{\circ} 47.98^{\prime}$ & 240 & 840 \\
\hline BLKS9810 & $44^{\circ} 04.04^{\prime}$ & $30^{\circ} 50.68^{\prime}$ & 378 & 759 \\
\hline
\end{tabular}

Radiocarbon age determinations were carried out at the ETH-Hoenggerberg AMS facility. Shells were leached prior to measurement to decrease the effects of diagenetic carbon contamination. 
For consistency with dates provided in previous publications, the dates presented here are the raw 14C measurements without additional corrections for reservoir age and calendar calibration.

Samples from both cores were analyzed for clay mineral content. After treatment for removal of carbonate, amorphous metal oxides, and amorphous silica, each sample was split into three size fractions ( $>20,2-20$, and $<2 \mu \mathrm{m}$ ), and each size fraction was weighed to determine grain size distribution. Oriented glass slide mounts were made of the $<2 \mu \mathrm{m}$ size fraction. The slides were each scanned three times on the Phillips X-Pert -MPRD X-ray Diffractometer, the first a long, continuous scan from 1 to $50^{\circ}$ (2-theta) with a dwell time of 5 seconds and a $2 \theta$ step size of 0.02 . Following the first scan, each sample was treated in a glycolated atmosphere for at least 24 hours to expand the smectite interlayers. The last two scans were conducted on the glycolated samples over shorter 2-theta ranges to determine the peak offset by expandable clays (smectite) and the ratio of kaolinite to chlorite. The clay mineral composition was calculated using the method of (Biscaye, 1965). The relative percentages should be viewed as semiquantitative results.

Carbonate content was measured using a UIC Incorporated model $5011 \mathrm{CO} 2$ coulometer attached to a model 5130 acidification module. Carbon and oxygen stable isotopes of the carbonate fraction were measured on a Micromass Optima mass spectrometer with Multiprep carbonate preparation device. Calibration to VPDB is via NBS-19 and an in house standard of similar isotopic composition, with a typical range in values for the standards of .05 for $\delta^{13} \mathrm{C}$ and .08 for $\delta^{18} \mathrm{O}$ ( 1 sigma standard deviation). Due to the lack of calcareous foraminifera or mollusks in most of the sediment samples, most isotopic analyses were conducted on bulk sediment samples. Samples were not treated to remove organic matter prior to acidification. Eight representative samples were viewed under a Scanning Electron Microscope (SEM) to determine 
the type of carbonate material present. Eight of the dated shells were also analyzed for $\delta^{18} \mathrm{O}$ and $\delta^{13} \mathrm{C}$.

\section{Results}

\section{Lithology}

Both cores contain Units 1, 2, and 3 of (Ross and Degens, 1974). Unit 1 is a coccolithbearing, light olive-gray, organic-rich and finely-laminated mud. Unit 2 is a dark olive-gray sapropel. Both units are thin $(<40 \mathrm{~cm})$ in the slope setting compared to their thickness in the deep basin $(\sim 70 \mathrm{~cm})$. Unit 3 shows variations in color from light gray to reddish brown. In the shallower core (BLKS9809) the uppermost part of Unit 3, comprising light gray to mottled black and darker gray muds, is missing. Unit 3 contains few mollusks, usually individual valves of small specimens of Dreissena rostriformis and rarely Turricaspia caspia. Units 1 and 2 are barren of mollusks.

Nine radiocarbon ages were measured on individual valves of mollusk shells (Table 2).

Table 2: Radiocarbon ages of mollusks from cores BLKS9809 and BLKS9810

\begin{tabular}{|l|l|l|l|l|l|}
\hline Core & Analysis \# & $\begin{array}{l}\text { Depth in core } \\
(\mathrm{cm})\end{array}$ & Species & Age (yrs) ** & $\begin{array}{l}\text { Error }( \pm 1 \sigma) \\
(\mathrm{yrs})\end{array}$ \\
\hline BLKS9810 & ETH-23298 & 94.5 & Turricaspia & 10,640 & 80 \\
\hline BLKS9810 & ETH-23299 & 118.5 & Dreissena & 11,410 & 110 \\
\hline BLKS9809 & ETH-22156 & 15 & Dreissena & 12,310 & 95 \\
\hline BLKS9810 & ETH-23300 & 154.5 & Dreissena & 12,790 & 110 \\
\hline BLKS9810 & ETH-23301 & 186.5 & Dreissena & 12,920 & 100 \\
\hline BLKS9809 & ETH-22157 & 115 & Dreissena & 14,010 & 100 \\
\hline
\end{tabular}




\begin{tabular}{|l|l|l|l|l|l|}
\hline BLKS9809 & ETH-21127 & 215 & Dreissena & 14,950 & 100 \\
\hline BLKS9810 & ETH-23302 & 704 & Dreissena & 17,760 & 130 \\
\hline BLKS9809 & ETH-21128 & 840 & Dreissena & 20,580 & 150 \\
\hline
\end{tabular}

** Uncorrected radiocarbon years

Table 3: Ages of Black Sea units and subunits.

\begin{tabular}{|c|l|l|}
\hline Description & $\begin{array}{l}\text { Thickness in cm } \\
\text { (BLKS9809/BLKS9810) }\end{array}$ & $\begin{array}{l}\text { Age range (uncorrected } \\
\text { radiocarbon years) }\end{array}$ \\
\hline Coccolith ooze (Unit 1) & $\left(20^{* / 16 *}\right)$ & $0-3,000$ \\
\hline Black Sea sapropel (Unit 2) & $\left(27^{*} / 23.5\right)$ & $3,000-7,100$ \\
\hline Neoeuxine muds (Unit 3) & & \\
\hline Late Neoeuxine & $(--/ 13)$ & $7,500-7,100$ \\
\hline Upper carbonate peak & $(--/ 30)$ & $9,700-7,500$ \\
\hline Carbonate trough & $(--/ 30)$ & $10,800-9,700$ \\
\hline Lower carbonate peak & $(--/ 32)$ & $12,800-10,800$ \\
\hline Transition & $(51 / 70)$ & $13,400-12,800$ \\
\hline Brown muds & $(194 / 120)$ & $>20,600-15,000$ \\
\hline Homogeneous gray muds & $(>580 />420)$ & \\
\hline
\end{tabular}

*thickness from pilot core

The high degree of visual and physical property core-to-core correlation allowed us to construct a consistent age model for both cores. Although core BLKS9809 has a gap in sedimentation between $\sim 12,000$ and 7,000 yrs, the deeper core, BLKS9810, contains a complete record from 18,000 yrs to the present (Table 3). Sedimentation rates decrease markedly at 12,800 and 7,100 yrs (Figure 3). 


\section{Clays and carbonates}

Both cores show an abrupt increase in the relative amount illite and kaolinite in the Unit 3 brown muds (C1 and 2 in Figure 3) at 15,000 yrs and a decrease beginning at 13,400 yrs (Figure 3). Smectite is a significant component prior to 15,000 yrs (Unit 3 gray muds) and in the interval from 10,800 to 9,700 yrs. Unit 1 is low in kaolinite and high in chlorite, and Unit 2 has a very similar clay mineral composition to the upper part of Unit 3. Sediments are coarsest between 11,200 and 10,000 yrs and 7,500 to 7,100 yrs.

Calcium carbonate content displays a narrow range from 9 to $13 \%$ in the Unit 3 homogeneous gray muds from the base of the cores up to $15,000 \mathrm{yrs}$. Within the brown clays of Unit 3 the carbonate content is lower overall, dipping to $6 \%$, and covaries with smectite content of the clay size fraction. Carbonate content rises gradually from 10 to $22 \%$ between 13,300 and $12,500 \mathrm{yrs}$, then increases abruptly to a peak of $42 \%$ at $11,400 \mathrm{yrs}$ (B2 in Figure 3). A second more pronounced peak in carbonate content (B1 in Figure 3), reaching over 60\% and lasting from roughly 10,000 to $7,500 \mathrm{yrs}$, follows an interval of low carbonate content between 11,100 and 10,000 yrs. The carbonate peaks are accompanied by the appearance of euhedral, silt-sized calcite grains. Carbonate in the rest of the core is a mixture of reworked coccoliths, mollusk shell fragments, and detrital carbonate grains.

\section{Stable isotopes}

The $\delta^{18} \mathrm{O}$ record of the bulk carbonate (Figure 3) in Unit 3 shows little variation prior to $15,000 \mathrm{yrs}$, ranging between -4.1 and -5 per mil and averaging -4.5 per mil. The values drop to -5.3 per mil between 15,000 and 12,850 yrs (Unit 3 brown muds and transition), then rise briefly 
to earlier values of $\sim-4.5$ before plunging to less than -7 per mil by 12,790 yrs (Unit 3-lower carbonate peak, B2). Values remain low, between -6.5 and -8.9 per mil, up to the top of Unit 3 . The $\delta^{18} \mathrm{O}$ within Unit 2 is higher, ranging from -3.4 to -4.8 per mil, and is highest, -0.2 per mil, in Unit 1. The $\delta^{18} \mathrm{O}$ of the mollusk shells shows a increasing trend starting at $12,800 \mathrm{yrs}$, rising from a baseline value of -7 per mil up to -3.1 at 10,640 yrs. The $\delta^{13} \mathrm{C}$ values of the bulk carbonate fraction range from -1.8 to +1.4 per mil within Unit 3 , showing the maximum variation between 15,000 and 12,300 yrs (Unit 3 brown muds and transition). There is an overall trend toward higher $\delta^{13} \mathrm{C}$ values between 12,300 and 7,880 yrs, with a short positive excursion between 11,000 and $10,000 \mathrm{yrs}$. The $\delta^{13} \mathrm{C}$ of Unit 2 varies from -0.2 to -1.0 per mil, and reaches the highest value of +1.8 per mil in Unit 1 . The $\delta^{13} \mathrm{C}$ of the mollusk shells displays two steps toward lower values, the first starting at 14,950 yrs and the second at 12,800 yrs.

All proxies suggest a brief return between 11,000 and 10,000 yrs to values that characterized Unit 3 prior to 15,000 yrs (homogeneous gray muds).

\section{Interpretation}

\section{Climate}

The climate of the deglaciation brought about changes in the hydrology of the Black Sea drainage, altering runoff by ice melt contribution, reconfiguring drainages because of ice retreat, and changing atmospheric circulation. The water balance of the glacial Black Sea would have differed in some important respects from the modern condition.

Pollen data (Allen et al., 1999; Filipova et al., 1983; Peterson, 1983; Tzedakis, 1999) reveal that during the last glacial period the areas north and west of the Black Sea were populated with a steppe vegetation dominated by Artemisia and Chenopodiaceae and indicative 
of cold, dry climate. At the same time lake shorelines on the Anatolian Plateau were high (Roberts et al., 1979), suggesting an inverse situation with less evaporation on the south side of the Black Sea. This low evaporation was most likely a consequence of low temperatures at high altitudes.

Beginning roughly 15,000 yrs the rapid retreat of large ice-caps and glaciers in northern Europe and the Alps contributed a burst of meltwater via the Dniepr and Danube Rivers that was concluded in less than two millennia and maybe only a few centuries (C. Schlüchter, personal communication). The Caspian Sea responded to this meltwater episode as well, rising to a Late Khvalynian high stand (Svitoch, 1999) that elevated its shoreline to the point of overflow into the Black Sea through the Manysch valley (Chepalyga, 1984; Ferronsky et al., 1998) and allowing migration of Caspian fauna. With the Caspian spilling into the Black Sea, it seems likely that the latter basin would have swelled to the level of its own outlet.

The onset of the Bolling-Allerod warm period at 13,200 yrs is marked by an increase in the percent of oak (Quercus) pollen, a sign of an expansion of woodlands and a reduction in the steppe vegetation (Traverse, 1974; Zonneveld, 1996). The cool Younger Dryas starting at 11,200 yrs marks a return to the steppe environment, followed at 10,000 yrs by a brief return to warm, moister conditions, then cooler, drier conditions again, then finally an abrupt shift at $\sim 7,000$ yrs from herb-dominated to tree-dominated assemblages coincident with the onset of anoxia at the base of Unit 2 (Atanassova, 1995; Traverse, 1974). Although there is an evolution in the Black Sea's surrounding vegetation beginning at 15,000 yrs, the most pronounced shift accompanies the onset of sapropel deposition (Filipova et al., 1983). Dinoflagellates show a shift from freshwater (stenohaline) to marine (euryhaline) species at 7,100 yrs (Atanassova, 1995; Wall and Dale, 1974); J.-P. Suc, personal communication). Achritarchs, a planktonic 
stage of marine plants, show an abrupt 50-fold increase in abundance at the base of Unit 2 (Traverse, 1974).

\section{Water budgets}

The melting of the ice caps over Scandinavia, the Barents shelf, and the Alps would enhance freshwater input to the Black Sea. At glacial maximum, the southern margin of the Scandinavian ice sheet fed pro-glacial lakes in the Dniepr River drainage basin (Grosswald, 1980). Paleohydrology of the upper Dniepr reveals braided stream deposits indicative of iceproximal high-energy discharge. These deposits are incised by underfit river-channel and overbank deposits dated 10,200 yrs, typical of modern lower energy flow (Kalicki and Sanko, 1998). The Pomeranian moraine of the Scandinavian ice sheet, marking the last advance into areas south of the Baltic Sea into Poland and Germany, is dated between 18,000 and 15,000 yrs (Denton and Hughes, 1981) (Figure 4). The Raunis interstadial, beginning at 14,000 yrs, marks the end of meltwater delivered into the Dniepr watershed.

Grosswald suggests an additional ice cap over the Kara Sea, to supply meltwater to the Black Sea via the Aral and Caspian Seas. The terminal moraines of the proposed Kara ice cap are poorly defined, and retreat from the Volga watershed would have been accomplished prior to 14,500 yrs (Peltier, 1993). The Alpine ice domes collapsed about the same time, retreating from the Swiss foreland to nearly their present positions between 14,600 and 14,200 yrs (C. Schlüchter, personal communication). There is little evidence to support a readvance of any of the ice caps south of the Baltic during the Younger Dryas cold period that could have resulted in significant enhancement of meltwater delivery to the Black Sea (Denton and Hughes, 1981). 
The clay mineral variations correlate with the timing of meltwater delivery. Prior to 15,000 the assemblage is relatively high in smectite, a mineral of Anatolian provenance (Muller and Stoffers, 1974). Permafrost in the northern drainage would inhibit erosion and thus limit the clays brought in from that region until thaw. Modern core top sediments show illite and kaolinite dominating the northwestern quadrant of the Black Sea (Muller and Stoffers, 1974). The appearance of these clays at 15,000 is coincident with the major collapse of the Scandanavian and Alpine ice domes. Although the moraines indicate that the melting was waning by 14,200 yrs, the continued supply of illite and kaolinite until 12,800 yrs can be explained by high erosion rates until vegetation is re-established in the drainage basin with the Bolling warming (Vanderberghe, 1995).

\section{Sea levels}

Our data show an important signal on the Romanian slope commencing at 12,800 yrs: 1) the sedimentation rate drops by a factor of five; 2) the $\delta^{18} \mathrm{O}$ of mollusk shells increases; 3 ) the $\delta^{18} \mathrm{O}$ of the bulk carbonate fraction decreases; 4) the carbonate content of the sediment increases from inorganic calcite precipitation; 5) the kaolinite content of the clay-size fraction drops, and 6) one observes the beginning of a trend toward smaller average grain sizes in the terrigenous component.

Soon afterwards the marine fauna appear in the Sea of Marmara (Cagatay et al., 2000). It is possible to envision a scenario with a deep Black Sea outlet such that the Black Sea became connected in tandem with Marmara. In support of such an hypothesis, the drop in sedimentation and decrease in grain size would signal a Black Sea coastal transgression concurrent with the rapid global sea level rise at the time of meltwater pulse 1A (Fairbanks, 1989). Entry of 
Mediterranean water into the Black Sea might well-explain the steady increase in $\delta^{18} \mathrm{O}$ of the mollusk shells that begins at 12,800 yrs. The light $\delta^{18} \mathrm{O}$ of the inorganic calcite may indicate a weakly or seasonally stratified water column brought about by this introduction of denser highsalinity deep water. The relationship between the bulk and shell isotopes suggests a complex system of multiple end-members affecting the isotopic composition, including freshwater biogenic (prior to 12,300 yrs), marine biogenic (after 3,000 yrs), detrital carbonate, and inorganic calcite.

Deposits with Neoeuxine fauna have been reported in depths of -20 to -30 meters on the inner shelf off Romania, Ukraine and Russia (Scherbakov et al., 1978). Although these sediments are not radiocarbon dated, they have been used to infer a freshwater transgression which flooded most of the shelf prior to a marine connection (Kuprin et al., 1974; Shimkus et al., 1978). Other deposits from the Sea of Azov and the near shore part of the Black Sea shelf that have been radiocarbon dated contain Cardiids more than 9,000 years old (Shcherbakov and Babak, 1979). One of our BLaSON cores (BLVK9814) at a depth of $-55 \mathrm{~m}$ contains such Cardiids dated at 9,580 yrs (Lericolais et al., in prep). These fauna are indicative of saline ponds, and their locations would have been above the Neoeuxine shoreline. Thus the Sea of Azov and inner Black Sea shelf had to have been dry land with relic brackish water bodies while the Black Sea lake was still fresh.

A shallow outlet would delay the entrance of Mediterranean water until its sill was breached. A warming climate with increased evaporation upon the conclusion of meltwater delivery at 14,000 yrs could place the Black Sea basin in a negative water balance. In this case the Black Sea could become like the Caspian Sea, with high stands during cold intervals and regressions during warm intervals. The increase in $\delta^{18} \mathrm{O}$ of the shells at $12,800 \mathrm{yrs}$ would have 
been the response to evaporative concentration of heavy oxygen. The peaks in inorganic calcite at 12,000 and 9,500 yrs would have been produced by evaporation and supersaturation of surface water. The decrease in inorganic carbonate and increase in grain size during the Younger Dryas result from an increase in runoff during a return to cold conditions, possibly due to a reconfiguration in atmospheric circulation (Florineth and Schluchter, 2000). This scenario is consistent with a nearshore/subaerial setting for the dunes and pans found on the Romanian shelf (Lericolais et al., in prep).

\section{Implications for the Sea of Marmara}

The two scenarios give very different predictions for outflow from the Black Sea to Marmara (Table 4). In the early-entry and deep-sill model, one must explain the absence of marine fauna (both planktonic and benthonic) in the Black Sea until 7,100 yrs. The delay in their appearance in the Sea of Marmara appears to be short. It is possible that the Sea of Marmara, with a smaller volume, reaches its salinity threshold more quickly with mixing, whereas the Black Sea requires a much greater amount of marine water to reach a value suitable for marine organisms. The drop in northern-sourced clays suggests a decrease in river input, which would necessitate less resistance to marine inflow. An early connection is not consistent with a relationship between freshwater outflow from the Black Sea and the formation of the sapropel in the Sea of Marmara, which does not begin until 10,600 yrs at the earliest (Cagatay et al., 2000). If the connecting sill was deep, one would expect that outflow would have been strong between 15,000 and 14,200 yrs when rivers were still loaded with meltwater. Marmara would then have received another important discharge after 12,500 yrs as the meltwater stored behind the Bosporus sill began to be displaced by Mediterranean inflow (Lane-Serff et al., 1997). During 
this time the deeper waters of Marmara and the Black Sea should have remained well -supplied in dissolved oxygen. The onset of anoxia in Marmara would signal the slowing down and perhaps completion of the displacement process.

If the late-entry and shallow-sill model described reality, one would predict Black Sea shorelines higher than time-equivalent shorelines of the Sea of Marmara at times of outflow. Such highstands have not been dated in Black Sea cores, but only inferred by the presence of freshwater deposits high on the shelf. If the connecting sill was shallow then the displacement of the Black Sea's deep freshwaters is delayed until the Bosporus barrier was breached. In the interim, outflow from the Black Sea to the Sea of Marmara would be non-existent during intervals when the Black Sea was in a Caspian model of evaporative drawdown, and outflow would be possible at time of lower evaporation such as during the Younger Dryas.

In order to distinguish between these two models, cores from the -15 to -40 m depth range on the Black Sea shelf should be examined for subaqueous deposition above world sea level.

In our cores from the mid shell we have dated prodelta deposits at a depth of --70 $\mathrm{m}$ at 23,600 yrs. Lake level then would have been higher than contemporary world sea level (Fairbanks, personal communication). Other means to distinguish between the two models would be to find a marine water proxy in the Sea of Marmara and Black Sea sediments that neither fractionates with evaporation nor changes with precipitation. Future work will focus on using strontium isotopes and $\mathrm{Sr} / \mathrm{Ca}$ ratios of calcareous shells to look and date changes in such signatures.

\section{CONCLUSIONS}


The Black Sea shows a marked change in sedimentation and oxygen isotopic composition at $12,800 \mathrm{yrs}$. If this change reflects an early connection with the Mediterranean via the Sea of Marmara, the Neoeuxine lake would rise with world sea level, and outflow via the Bosporus Strait would have remained uninterrupted. The Black Sea would have never stood above the level of the Dardanelles Sill (-85 m) during glacial times. The delay in the introduction of marine fauna and flora in the Black Sea until 7,100 yrs requires a gradual salinification to a threshold suitable for these organisms.

If the change in sedimentation happens with a shallow sill, then the Black Sea in glacial and early post-glacial time must be responding solely to the basin freshwater budget and regional climate. In this case deep shorelines require episodes of evaporitic drawdown and a transformation to a Caspian mode. The Black Sea cannot outflow during such periods. Although the stratification of the Sea of Marmara beginning as early as 10,600 yrs favors the deep sill model, it cannot be embraced until the evidence of apparent late Neoeuxine deep shorelines in the Black Sea is explained by other phenomena. 


\section{FIGURE CAPTIONS}

Figure 1: Map of the Black Sea showing core locations. Contour interval is $500 \mathrm{~m}$.

Figure 2: Summary of core analyses plotted versus age in uncorrected radiocarbon years. The shaded area marked "A" indicates the marine part of the section, including Units 1 and 2 of Ross and Degens (1974). "B1" and "B2" are the upper and lower carbonate peaks, respectively. "C1" and "C2" are the brown clay beds.

Figure 3: Sedimentation rates of cores BLKS9809 and BLKS9810, showing marked changes at 12,800 and $7,100 \mathrm{yrs}$.

Figure 4: Ice coverage in Europe at the last glacial maximum, 13,000 yrs, and present day (adapted from Denton and Hughes, 1981).

Figure 5: Summary of shallow and deep sill models, indicating possible periods of exchange between the Black Sea, Sea of Marmara, and the Aegean. Curved arrows indicate water exchange over the Dardanelles and Bosporus sills. Straight arrows indicate strength of river inflow (thickness is proportional to flow). Lightest shading indicates freshwater, medium shading indicates marine water, and darkest shading indicates anoxic water. 


\section{REFERENCES}

Aksu, A.E., Hiscott, R.N. and Yasar, D., 1999. Oscillating Quaternary water levels of the Marmara Sea and vigorous outflow into the Aegean Sea from the Marmara Sea-Black Sea drainage corridor. Marine Geology, 153(1-4): 275-302.

Aksu, A.E., Yasar, D., Mudie, P.J. and Gillespie, H., 1995. Late glacial-Holocene paleoclimatic and paleoceanographic evolution of the Aegean Sea: micrpaleontological and stable isotopic evidence. Marine Micropaleontology, 25: 1-28.

Allen, J.R. et al., 1999. Rapid environmental changes in Southern Europe during the last glacial period. Nature, 400: 740-743.

Atanassova, J., 1995. Dinoflagellate cysts of late Quaternary and recent sediments from the western Black Sea. Annual of the University of Sofia "St. Kliment Ohridski", Faculty of Biology, 87(Book 2, Botany): 17-28.

Ballard, R.D., Coleman, D.F. and Rosenberg, G.D., 2000. Further evidence of abrupt Holocene drowning of the Black Sea shelf. Marine Geology, 170: 253-261.

Biscaye, P.E., 1965. Mineralogy and sedimentation of recent deep-sea clay in the Atlantic Ocean and adjacent seas and oceans. Geological Society of America Bulletin, 76: 803-832.

Cagatay, M.N. et al., 2000. Late glacial-Holocene palaeoceonography of the Sea of Marmara: timing of connections with the Mediterranean and the Black Seas. Marine Geology, 167: 191-206.

Chepalyga, A.L., 1984. Inland sea basins. In: A.A. Velichko (Editor), Late Quaternary Environments of the Soviet Union. University of Minnesota Press, Minneapolis, MN, pp. 229-246. 
Denton, G.H. and Hughes, T.J., 1981. The last great ice-sheets. John Wiley \& Sons, New York, $484 \mathrm{pp}$.

Dimitrov, P., 1982. Radiocarbon datings of bottom sediments from the Bulgarian Black Sea shelf. Oceanology, 9: 45-53.

Fairbanks, R.G., 1989. A 17,000-year glacio-eustatic sea level record: influcence of glacial melting rates on the Yonger Dryas event and deep-ocean circulation. Nature, 342(6250): $637-642$.

Ferronsky, V.I. et al., 1998. Isotope studies of the Caspian Sea: Climatic record from bottom sediments (preliminary results), International Symposium on Isotope Techniques in the Study of Past and Current Environmental Changes in the Hydrosphere and the Atmosphere. IAEA, Vienna, Austria, pp. 633-644.

Filipova, M.V., Boxilova, E.D. and Dimitrov, P.S., 1983. Palynological and stratigraphical data about the Quaternary from the southern part of the Bulgarian Black Sea shelf. Oceanology, Journal of the Bulgarian Academy of Sciences, 11: 24-32.

Florineth, D. and Schluchter, C., 2000. Alpine evidence for atmospheric circulation patterns in Europe during the Last Glacial Maximum. Quaternary Research, 54: 295-308.

Göksu, H.Y., Özer, A.M. and Çetin, O., 1990. Mollusk kavkilarinin elektron spin rezonans (ESR) yontemi ili tarihlendirilmesi. In: E. Meriç (Editor), Late Quaternary (Holocene) Bottom Sediments of the Southern Bosphorus and Golden Horn. Matbaa Teknisyenleri Basimevi Divanyolu, Istanbul, pp. 95-97.

Grosswald, M.G., 1980. Late Weichselian ice sheet of Northern Europe. Quaternary Research, 13: $1-32$. 
Jones, G.A. and Gagnon, A.R., 1994. Radiocarbon chronology of Black Sea sediments. Deep Sea Research, 41(3): 531-557.

Kalicki, T. and Sanko, A.F., 1998. Palaeohydrological changes in the Upper Dneper Valley, Belarus, during the last 20,000 years. In: G. Benito, V.R. Baker and K.J. Gregory (Editors), Palaeohydrology and Environmental Change. John Wiley \& Sons, Ltd., Chichester, England, pp. 125-135.

Kuprin, P.N., Scherbakov, F.A. and Morgunov, I.I., 1974. Correlation, age, and distribution of the postglacial continental terrace sediments of the Black Sea. Baltica, 5: 241-249.

Kvasov, D.D., 1968. Paleohydrology of eastern Europe in late Quaternary time, Yezhegodnkkh Chetniyakh Pamyati L.S. Berga Doklady. Izd. Nauka, Leningrad, pp. 65-81.

Kvasov, D.D., 1975. Late Quaternay History of Major Lakes and Inland Seas of Eastern Europe. Naula Press, Leningrad.

Lane-Serff, G.F., Rohling, E.J., Bryden, H.L. and Charnock, H., 1997. Post-glacial connection of the Black Sea to the Mediterranean and its relation to the timing of sapropel formation. Palaeoceanography, 12(2): 169-174.

Lericolais, G. et al., in prep. Dunes and pans on the Black Sea shelf.

Muller, G. and Stoffers, P., 1974. Mineralogy and petrology of Black Sea sediments. In: E.T. Degens and D.A. Ross (Editors), The Black Sea: Geology, Chemistry, and Biology. American Association of Petroleam Geologists, Tulsa, OK, pp. 200-248.

Olausson, E., 1961. Studies of deep-sea cores. Reports of the Swedish Deep-Sea Expedition, VIII(6): 336-391. 
Ozdogan, M., 1990. Tarih Oncesi Donemde Marmara Bolgesi. In: E. Meric (Editor), Late Quaternary (Holocene) bottom sediments of the southern Bosporus and Golden Horn. Istanbul Technical University, Istanbul, pp. 107-111.

Peltier, W., 1993. Time Dependent Topography Through Glacial Cycle. Series \# 93-015, IGBP PAGES/World Data Center-A for Paleoclimatology Data Contribution. NOAA/NGDC Paleoclimatology Program, Boulder CO, USA.

Peterson, G.M., 1983. Recent pollen spectra and zonal vegetation in the western USSR. Quaternary Science Reviews, 2: 281-321.

Roberts, N., Erol, O., de Meester, T. and Uerpmann, H.-P., 1979. Radiocarbon chronology of late Pleistocene Konya Lake, Turkey. Nature, 281: 662-664.

Ross, D.A. and Degens, E.T., 1974. Recent sediments of the Black Sea. In: E.T. Degens and D.A. Ross (Editors), The Black Sea: Geology, Chemistry, and Biology. American Association of Petroleam Geologists, Tulsa, OK, pp. 183-199.

Ryan, W.B.F. et al., 1997. An abrupt drowning of the Black Sea shelf. Marine Geology, 138: $119-126$.

Scherbakov, F.A. et al., 1978. Sedimentation on the Continental Shelf of the Black Sea. Nauka Press, Moscow, 211 pp.

Scholten, R., 1974. Role of the Bosporus in Black Sea chemsitry and sedimentation. In: E.T. Degens and D.A. Ross (Editors), The Black Sea: Geology, Chemistry, and Biology. American Association of Petroleam Geologists, Tulsa, OK, pp. 115-126.

Shcherbakov, F.A. and Babak, Y.V., 1979. Stratigraphic subdivision of the Neoeuxinian deposits in the Black Sea. Oceanology, 19(3): 298-300. 
Shimkus, K.M., Evsyukov, Y.D. and Solovjeva, R.N., 1980. Submarine terraces of the lower shelf zone and their nature. In: Y.P. Malovitsky and K.M. Shimkus (Editors), Geological and Geophysical Studies of the Pre-Oceanic Zone. P.P. Shirshov Inst. of Oceanology Acad. Sci. USSR,, Moscow, pp. 81-92.

Shimkus, K.M., Komarov, A.V. and Grakova, I.V., 1978. Stratigraphy of the upper Quaternary deep sea sediments in the Black Sea. Oceanology., 17(4): 443 -446.

Stanley, D.J. and Blanpied, C., 1980. Late Quaternary water exchange between the eastern Mediterranean and the Black Sea. Nature, 285(5766): 537-541.

Svitoch, A.A., 1999. Caspian Sea level in the Pleistocene: Hierarchy and position in the paleogeographic and chronological records. Oceanology, 39(1): 94-101.

Traverse, A., 1974. Palynologic investigation of two Black Sea cores. In: E.T. Degens and D.A. Ross (Editors), The Black Sea: Geology, Chemistry, and Biology. American Association of Petroleam Geologists, Tulsa, OK, pp. 381-388.

Tzedakis, P.C., 1999. The last climatic cycle at Kopais, central Greece. Journal of the Geological Society, London, 156: 425-434.

Ünlüata, Ü., Oguz, T., Latif, M.A. and Özsoy, E., 1989. On the physical oceanography of the Turkish Straits. In: L.J. Pratt (Editor), The Phusical Oceanography of Straits. NATO/ASI Series, Kluwer, Deventer, THe Netherlands, pp. 25-60.

Vanderberghe, J., 1995. Timescales, climate and river development. Quaternary Science Reviews, 14: 631-638.

Wall, D. and Dale, B., 1974. Dinoflagellates in the late Quaternary deep-water sediments of the Black Sea. In: E.T. Degens and D.A. Ross (Editors), The Black Sea - Geology, Chemistry and Biology. Amer. Assoc. Petrol. Geol. Mem., Tulsa, pp. 364-380. 
Yilmaz, Y. and Sakinc, M., 1990. Istanbul Bogazinin Jeolojik Gelisimi Uzerine Dusunceler. In: E. Meric (Editor), Late Quaternary (Holocene) bottom sediments of the southern Bosporus and Golden Horn. Istanbul Technical University, Istanbul, pp. 99-105.

Zonneveld, K.A.F., 1996. Palaeoclimatic reconstruction of the last deglaciation (18-8 ka B.P.) in the Adriatic Sea region; a land-sea correlation based on palynological evidence.

Palaeogeography, Palaeoclimatology, Palaeoecology, 122: 89-106. 


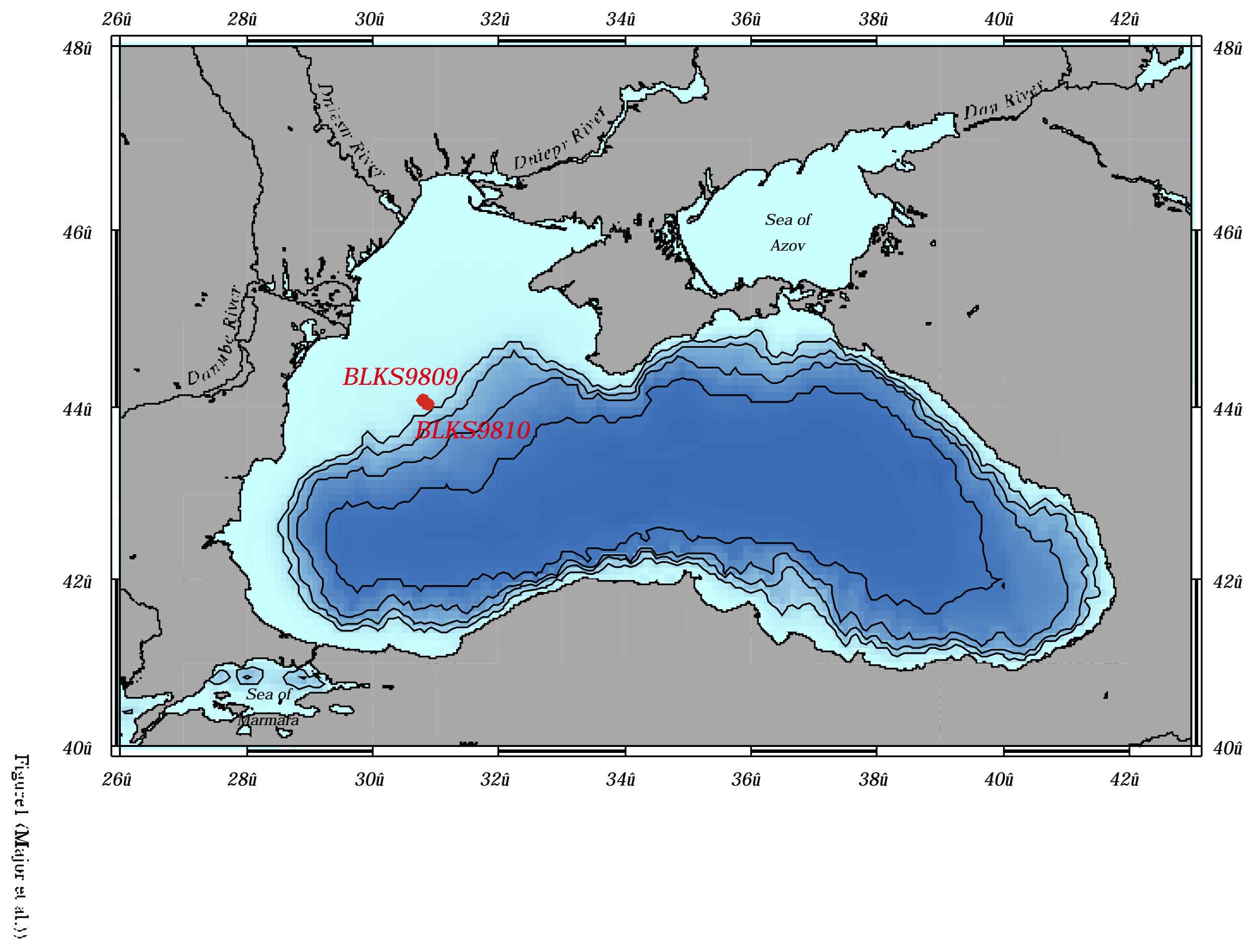




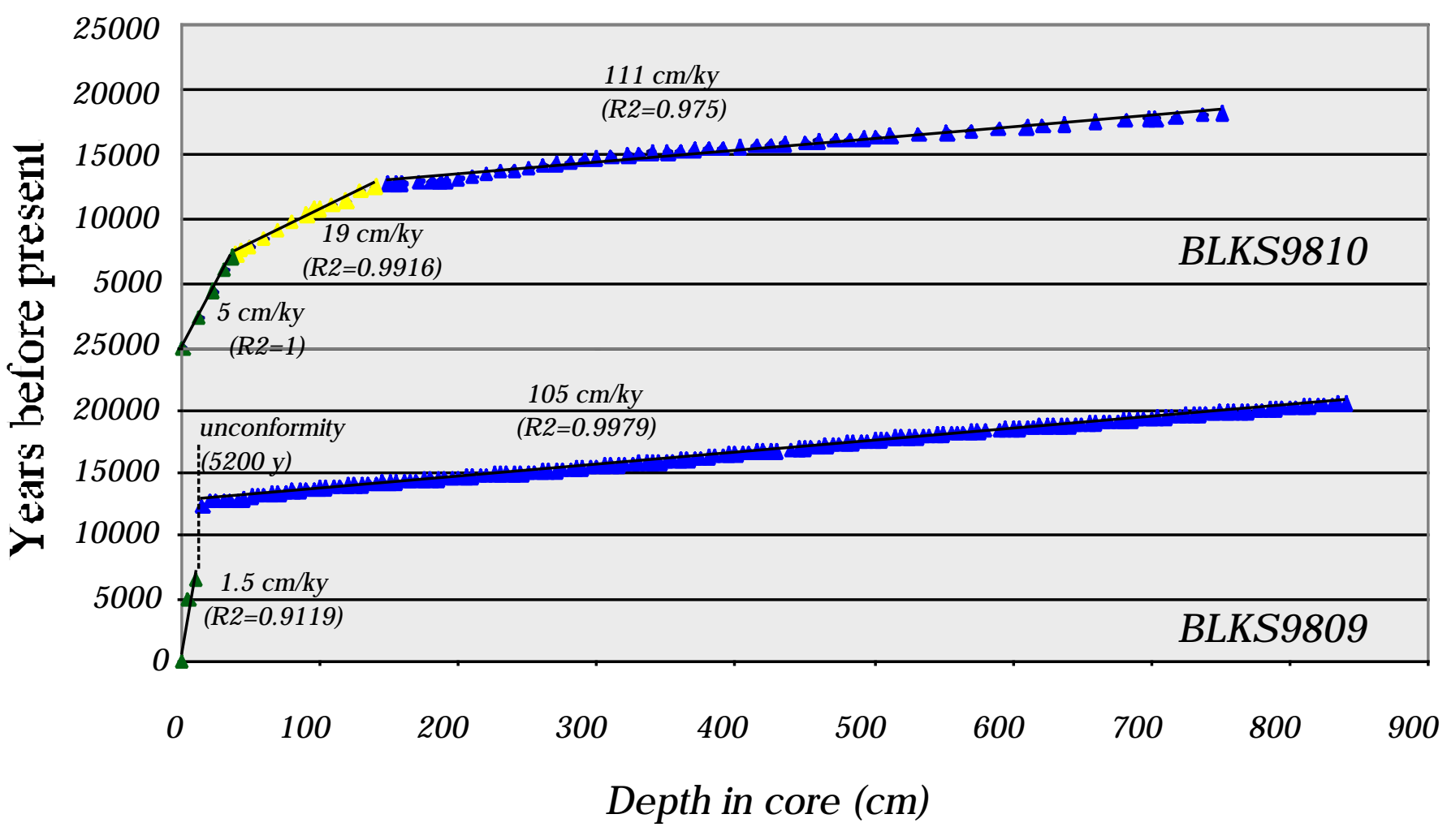

Figure 2 (Major et al.) 


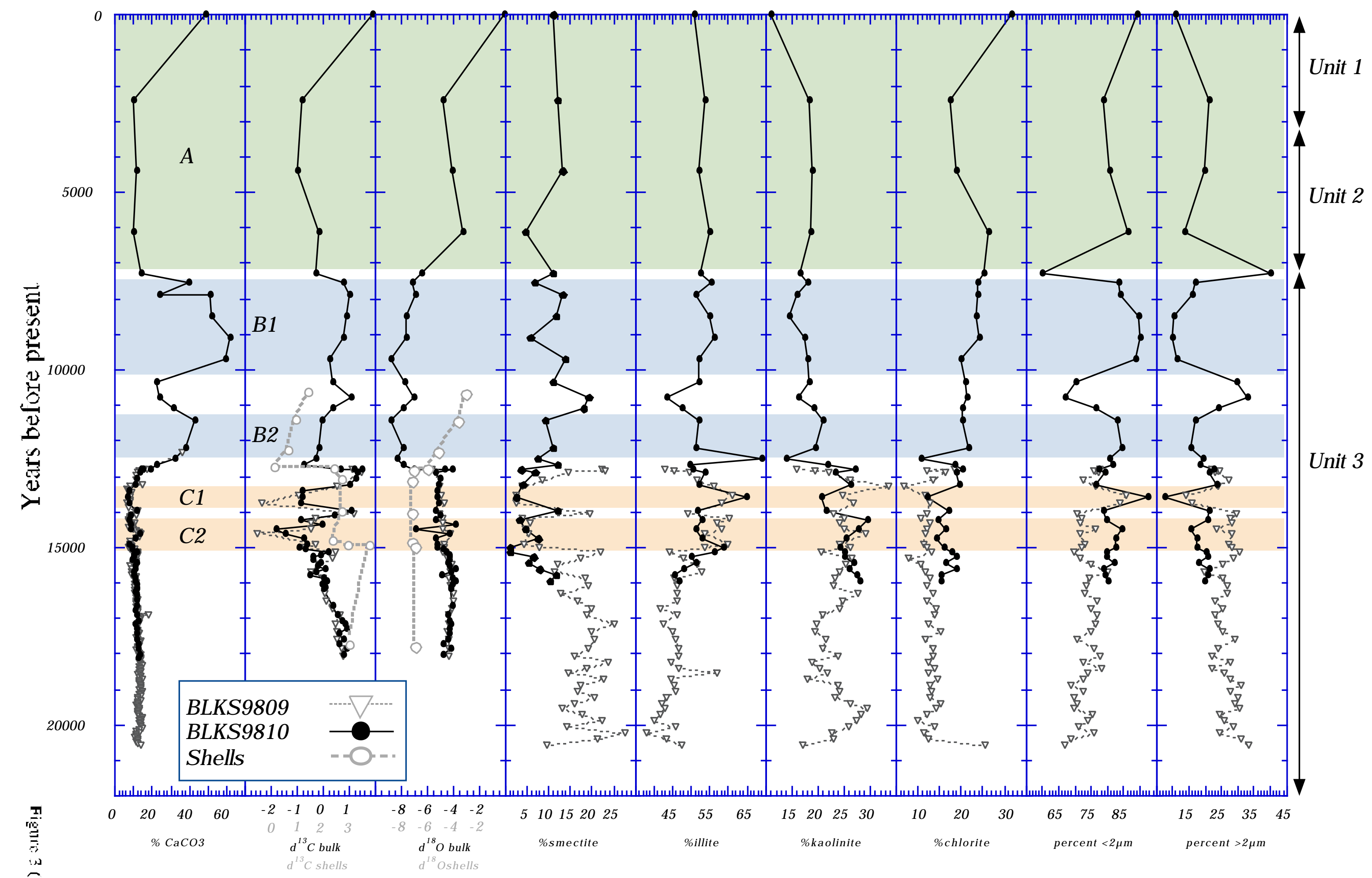


Table 4:

\begin{tabular}{|c|c|c|c|c|c|c|c|c|c|c|c|c|c|}
\hline $\begin{array}{l}\text { Time } \\
\text { period }^{1}\end{array}$ & $\begin{array}{l}\text { Sedimentation } \\
\text { rate }\end{array}$ & $\begin{array}{l}\text { Authigenic } \\
\text { carbonate }\end{array}$ & \begin{tabular}{|l|} 
Clay \\
provenance
\end{tabular} & Fauna & Flora & \begin{tabular}{|l|}
$\begin{array}{l}\text { Caspian Sea } \\
\text { level }^{2}\end{array}$ \\
\end{tabular} & Sapropels & $\begin{array}{l}\text { Mediterranean } \\
\text { Sea level }^{3}\end{array}$ & $\begin{array}{l}\begin{array}{l}\text { Konya } \\
\text { Lake } \\
\text { (Anatolia) }^{4}\end{array} \\
\end{array}$ & $\begin{array}{l}\text { River } \\
\text { input }\end{array}$ & Evaporation & \begin{tabular}{|l} 
Outflow- \\
Shallow sill \\
model \\
\end{tabular} & $\begin{array}{l}\text { Outflow- } \\
\text { Deep sill model }\end{array}$ \\
\hline $25-15$ & High & None & South & Fresh & Steppe & Highest & None & $109 \mathrm{~m}$ & High & High & Low (cold) & Strong outflow & Strong outflow \\
\hline 15-12.8 & High & None & North & Fresh & Steppe & Falling & None & $94 \mathrm{~m}$ & Low & Very high & Increasing & Decreasing & Yes \\
\hline $12.8-11$ & Moderate & Hgih & Mixed & Fresh & $\begin{array}{l}\text { Mixed } \\
\text { Woodland } \\
\text { /steppe }\end{array}$ & Falling & None & $64 \mathrm{~m}$ & Gone & Low & High & No & Yes \\
\hline $11-10$ & Moderate & Low & South & $\begin{array}{l}\text { Slightly } \\
\text { brackish }\end{array}$ & Steppe & Low & None & $48 \mathrm{~m}$ & Gone & Moderate & Low & Possible & Yes \\
\hline $10-8.4$ & Moderate & High & Mixed & Brackish & \begin{tabular}{|l} 
Mixed \\
woodland/ \\
steppe
\end{tabular} & Low & $\begin{array}{l}\text { Marmara, } \\
\text { Aegean, E. } \\
\text { Mediterranean }\end{array}$ & $24 \mathrm{~m}$ & Gone & Low & High & No & Yes \\
\hline $8.4-7.1$ & Low & Decreasing & Mixed & \begin{tabular}{|l|}
$\begin{array}{l}\text { More } \\
\text { brackish }\end{array}$ \\
\end{tabular} & Steppe & Low & $\begin{array}{l}\text { Marmara, } \\
\text { Aegean, E. } \\
\text { Mediterranean }\end{array}$ & $13 \mathrm{~m}$ & Gone & Moderate & Decreasing & Possible & Yes \\
\hline 7.1-0 & Low & None & Mixed & Marine $^{5}$ & Woodland & Low & $\begin{array}{l}\text { Black Sea, } \\
\text { Marmara }\end{array}$ & $0 \mathrm{~m}$ & Gone & Moderate & Moderate & Moderate & Moderate \\
\hline
\end{tabular}

${ }^{1}$ Uncorrected radiocarbon years

${ }^{2}$ From Svitoch (1999)

${ }^{3}$ From Fairbanks (1989), uncorrected for marine reservoir age (460 y)

${ }^{4}$ From Roberts (1983)

${ }^{5}$ Species of Mediterranean affinity 